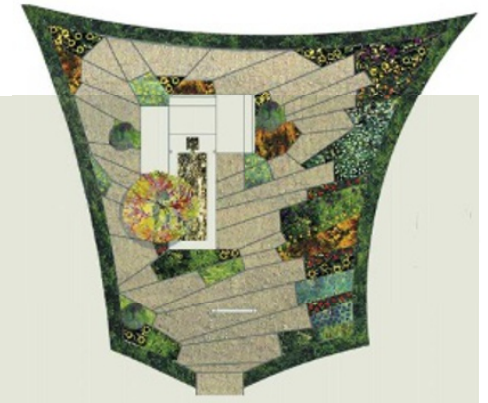

GLORIOUS GARDENS

The chateau grounds at Chaumont-sur-Loire, France, form the backdrop for a contemporary garden festival, running until October. Sustainability, biodiversity, bees and pollination, taste buds and continental drift are among the ideas brought to life in plants by top landscape designers, mirroring the festival's theme of partage, or division and sharing. www.chaumont-jardins.com

\section{ANIMAL PASSIONS}

Sexuality in the animal kingdom is the subject of an exhibition running until Spring 2009 at New York City's Museum of Sex. The show, advised by Stanford University ecologist Joan Roughgarden and other scientists, suggests that sex has various roles beyond reproduction and mating. Challenging the simple evolutionary theory of sex selection, Roughgarden aims to change our view of sexual behaviours to a more nuanced one, including orientation and cognition. www.museumofsex.com

\section{HEAVENLY HOUSES}

The buildings of influential twentieth-century architect John Lautner are showcased in Between Earth and Heaven at the Hammer Museum, Los Angeles, until 12 October. Having mainly worked in California, Lautner famously designed modern homes that are open to the environment, use innovative materials and take on futuristic shapes.

www.hammer.ucla.edu

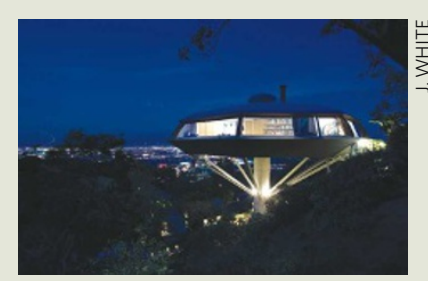

or casual use of evidence to form beliefs, whereas Asperger's syndrome may be marked by a desire for very tight, unambiguous evidence as a basis for forming beliefs. We now also know that autism is lifelong, and the old view that this was just a condition of childhood has meant there have been few, if any, studies of autism-spectrum conditions in adulthood.

One narrow slice of the autism spectrum disproportionately dominates public perceptions of the conditions. In the 1988 movie Rain Man, Dustin Hoffman's character Raymond Babbitt could impressively recall all airline crashes by date of incident, or could tell a waitress her phone number just from seeing her name badge, having memorized the local phone directory up to the letter G. Kim Peek, the real man on whom Babbitt is based, is even more impressive. He can recall every word of every one of the thousands of books he has ever read, and can read two facing pages of a book simultaneously. Interestingly, he also completely lacks a corpus callosum, the connective tissue between the two hemispheres of the brain, which may be related to his remarkable skills. Peek was described as a 'living Google' in a British television documentary about him in February 2006. Another documentary in 2007, entitled Brain Man, featured Daniel Tammet, a British man with Asperger's syndrome and synaesthesia, who memorized pi to 22,514 decimal places.

TV documentaries and box-office successes such as Rain Man have educated the public only about the savant subtype of autism. This same bias appears in best-selling novels too. The central character Christopher in The Curious Incident of the Dog in the Night-Time by Mark Haddon (Jonathan Cape, 2003) was a boy assumed to have Asperger's syndrome who, despite his limited social understanding, took advanced mathematics exams at the age of 13.
In such books and films, it is fiction that ends up educating the largest audience about autism.

Murray discusses why art is attracted to autism. We are fascinated, he posits, because autism seems to strike at the neural systems that define us as a species: the ability to pretend and deceive flexibly, to communicate through hints and innuendo, and to respond with empathy. At the same time, autism can, in some cases, facilitate other systems that also define us as a species, such as the ability to do mathematical calculations. Murray suggests the range of representations of autism in fiction include Spock from Star Trek and Sherlock Holmes.

Slanted views about autism can even be found in the research community. On the website of Autism Speaks, the major charity funding autism research in the United States, are the words "This disease has taken our children away. It's time to get them back." This is as clear a statement as one can find of autism as a disease, a view that many but not all autism scientists would endorse. Contrast this with Amanda Baggs's online video In My Language (http://tinyurl.com/2pczl2), which she launched as a statement about her civil rights as a person with autism, to be recognized and understood as different but not diseased. Another website, Autistics.org, proudly proclaims that people with autism are simply differently wired, and names one of their online groups the Autistic Liberation Front. These statements, along with Representing Autism, serve as a valuable reminder that we need to challenge how we conceptualize such medical conditions.

Simon Baron-Cohen is director of the Autism Research Centre, University of Cambridge, Cambridge CB2 8AH, UK. His latest book is Autism and Asperger Syndrome: The Facts. e-mail: sb205@hermes.cam.ac.uk

\title{
Visions of our far future
}

\section{Year Million: Science at the Far Edge of Knowledge \\ Edited by Damien Broderick \\ Atlas: 2008.330 pp. $\$ 40.00, £ 20.35$}

The Victorians' discovery of deep geological time was unsettling. Suddenly, human history was an afterthought, a link between an unthinkably long past and a newly imaginable future. H. G. Wells and his heirs, from Olaf Stapledon and J. D. Bernal to Freeman Dyson, tried to sketch what might come in the millennia after us. Today, most futurists are preoccupied with the problems of the next ten decades, although a few bright-eyed fabulists still scan the far horizon. Australian author and critic Damien Broderick brings them together in this mind-expanding volume of essays.

A million years, or 40,000 generations, is a long time - but not that long on a cosmic timescale. As Broderick puts it, the number is an emblem of a remote future. Most of the book's contributors pitch their remarks around this target, even though some believe the next few hundred years will see the advent 